\title{
非 $\boldsymbol{\gamma}$-globulin 型非定型抗体検出用の抗ヒト補体 血清のつくり方の研究
}

\author{
札幌市立病院内科 \\ 宮田亮 \\ 東京大学医学部血清学教室 \\ 目美津子松橋面

\section{STUDIES ON THE PRODUCTION OF ANTI-HUMAN COMPLEMENT ANTIBODIES FOR DETECTION OF NON-r-GLOBULIN TYPE INCOMPLETE ANTIBODIES.}

by

Makoto MiYata

The Department of Internal Medicine, Sapporo City Hospital

Mitsuko Usu and Tyoku MATUHASI

The Department of Serology, Faculty of Medicine, University of Tokyo

\begin{abstract}
The method for producing anti-human complement antibodies previously reported by Matuhasi and Usui was further investigated. The immunization of rabbits was carried out as follows: Egg white saline to 1:5 and antiegg white rabbit serum were mixed together with fresh human serum at the serological optimum ratio. After the precipitate was centrifuged, the complement titer of the supernatant was titrated. It was found that the titers were one tenth or one fortyfifth of the initial titer of the fresh serum, in other words, about 60 to 100 units of complement were fixed to the precipitate.

The three times washed precipitate was injected into rabbits subcutaneously twice a week for 3 to 4 weeks. Ten days after the last injection the rabbits were bled and the obtained antisera were tested by direct and indirect Coombs tests, the Ouchterlony technique and the analysis by the field reaction of the ring test. It was confirmed from these techniques that the antisera contained mainly anti-non- $\gamma$-globulins, in particular anti-complement antibodies.
\end{abstract}

The anti-human globulin antisera containing mainly anti- $\gamma$-globulin were prepared by immunizing the rabbit red blood cells treated with the heated supernatants which human complement had already been absorbed with the precipitate. The rabbit red blood cells were expected to be coated by human heteroantibodies belonging to the $\gamma$-globulin and to fix only small quantity of complement. In fact it was observed by the various serological techniques that the immunized rabbits mainly produced anti- $\gamma$-globulin antibodies.

These findings would lead to the conclusion that anti-human complement antibodies can be easily produced by immunization with antigen-antibody complex which is able to fix human complement.

Coombs 試験によつて見出される非定型自己 抗体は $\gamma$-globulin に属すると考えられていたが Dacie, Mollison 等 ${ }^{1)}$ の研究により非定型冷式抗 体, 抗 Lea あるいは抗 $\mathrm{P}$ 非定型抗体のあるもの らは, むしろ抗- $\alpha-,-\beta$-globalin 抗体のみを含む 抗血清で証明されることがわかり，このことか 
ら最近は, 抗- $\gamma$-globulin 抗体によつて検出される非定型自己抗体を $\gamma$-globulin 型抗体といい， 抗- $\alpha-,-\beta$-globulin 抗体で検出される抗体を非- $\gamma$ globulin 型抗体， あるいは補体結合性抗体と呼 ぶようになつた。この非- $\gamma$-globulin 抗体も実際 には $\gamma$-globulin に属するのであるが，非- $\gamma$ globulin（おそらく補体）が感作赤血球の表面に 結合しているため，一見非- $\boldsymbol{\gamma}$-globulin 抗体が結 合しているょうな態度をとるものであろうといわ れている。

彼等が上記の事実を証明するにあたつて，一応 純粋と考えられる抗- $\gamma$-globulin 血清及び抗一 $\alpha$,$\beta$-globulin 血清をもちいたのであるが，前者は ヒト血清でウサギを免疫してえられた抗ヒト血清 を, agamma-globulinemia の患者血清で吸収 してつくつたものであり，かかる患者が比較的稀 であるところから，いつでもこのような方法が簡 単に利用出来るものではない. 又後者の抗血清 として Mollison がもちいたものは Gel12) が供 給したものであるが，ヒト血清でウサギを免疫 して偶然にも抗- $\gamma$-globulin を含まず，抗非- $\gamma$ globulin のみをふくむ血清がえられたものであ るという．Gell の発見は多分に偶然的な所産の ように思えるが，このことはわれわれの前回の報 告4) からもわかるように在疫の比較的早期に採血 日を適当にえらべば容易にうることができるが， 才価の高いものはえがたいし，又理論的に確实な 方法とはいい難い，さきにわれわれは，卵白と それに対応するウサギの抗体との沈降物にヒト，血 清補体を結合させたものでウサギを免疫すると， ヒト血清の補体成分に対する抗体をつくること を経験したので，抗非- $\gamma$-globulin 抗体あるいは 祅- $\gamma$-globulin 抗体のみを夫々単独に含む抗血清 を，一定の方法で確実にえようとして，つぎのよ うな実験をおこない，注目すべき結果がえられた ので，つぎに報告する。

\section{実験方法}

1. 免疫方法 a) 抗-非- $\gamma$-globulin 血清（抗 ヒト補体血清）のつくり方：まず抗ニワトリ卵白 ウサギ血清 $(a b)$ ・ 5 倍稀橎ニワトリ卵白 $(\mathrm{Ew})$
反応系の最適比を，沈降反応重層法による場の 形，混合法および補体結合反応等から求める。こ の最適比の $\mathrm{Ew}$ と $\mathrm{ab}$ に, 補体として $\mathrm{Ew}$ (1: 5 ) 飞等量の新鮮ヒト血清 $\left(\mathrm{HC}^{\prime}\right)$ を加える. 沈 降物を大量にうるため，たとえば，ab：Ewの最 適比が 1 ：2 であつたらば, ab $5 \mathrm{ml}, \mathrm{HC}^{\prime} 10 \mathrm{ml}$, $\mathrm{Ew} 10 \mathrm{ml}$ の順序で混合し, 一昼夜水室に放置後 遠沈，えられた沈降物を更に泠却遠沈により生理 食塩水で 3 回洗う。最後の遠心沈渣に $6 \mathrm{ml}$ の生 理食塩水を加え，その $2 \mathrm{ml}$ 宛を 3 匹のウサギに 週 $1 \sim 2$ 回, 総計 $5 \sim 8$ 回皮下注射し, 最終注射 より10日目に全採血した。この抗血清を抗とト補 体血清（抗 $\mathrm{Ew} \mathrm{ab} \mathrm{HC}^{\prime}$ ) と名ずける.

b) 抗- $\gamma$-globulin 血清（抗-RRC ・ nha ( $\left.\mathbf{H C}^{\prime}\right)$ のつくり方： a）の混合液の遠沈上清 は後述のように大部分補体を消費されたヒト血清 を含んでいるわけであるが，一部（約 $3 \mathrm{ml}$ ）を 後述の補体価測定用に氷窒に保存し, 残りの約 20 $\mathrm{ml}$ を加温 ( $56^{\circ} \mathrm{C} 30$ 分) する.この加温上清の $1 / 3$ すなわち約 $7 \mathrm{ml}$ 宛を, 食塩水で 3 回洗つた 3 匹

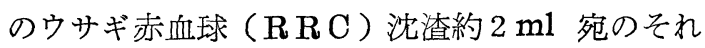
ぞれに加えて， $37^{\circ} \mathrm{C}$ のブネに 2 時間保つ。これ を食塩水で 3 回洗つたのち，再びそれぞれの元 のウサギの皮下に注射する．要するに上清中に 含まれるとト血清中の R R C に対する異種凝集素 （nha）で感作された R R C を再び元のウサギに 自家注射したわけである。このような免度注射を 週 $1 \sim 2$ 回, 計 $6 \sim 8$ 回くり返し, 最終注射より 10日目に全採血した.この抗血清を抗- $\gamma$-globulin 血清（抗-RRC nha (一

\section{2. 補体価の測定}

免疫の前日すなわち上述の抗原作製時もちいた 新鮮ヒト血清を一部翌日までドライアイス中で凍 結保存したものと，1・b）で不活性化せずに保 存した上清の両者を同時に測定した。

測定方法は Wassermann 反応緒方法の補体 価測定に準じたが，補体として使用した新鮮とト 血清は20倍および40倍稀釈とし，上清はそのまま もちいた（但し上清中のヒト血清はこの場合 $\mathrm{Ew}$ および $\mathrm{ab}$ で 2.5 倍に稀释されている). 光電比色 
計を用いて測定する関係上，各成分（補体， $\mathrm{Mg}$ 食塩水および $2 \%$ 感作ヒツジ血球）を緒方法の補 体価測定の場合の倍量宛混合し， $37^{\circ} \mathrm{C} ， 30$ 分工 ブネで加温したのち, 各試験管に更に $\mathrm{Mg}$ 食塩水 を $2 \mathrm{ml}$ 宛加え総量を $4 \mathrm{ml}$ とし, これを遠沈, その上清について溶血度を光電比色計（日立製U 型, 波長 $530 \mathrm{~m} \mu$ ) をもちいて比色し， $50 \%$ 溶血 価を求め, それぞれの補体単位を測定した。

\section{Coombs 血清 (抗-globulin 血清) の血清}

\section{学的検定.}

上述の免疫方法でえた 2 種類の抗血清につい て, 夫々免疫電気泳動法 (Grabar 法), Ouchterlony 法, 沈降反応重譄法, 間接 Coombs 試 験を試みた。

\section{実験成績}

1. 抗原抗体複合物によるヒト補体の結合 : 各 回免疫抗原作製時における新鮮とト血清と上清の 補体価測定值は表 1 の通りである。すなわち上清

表 1 新鮮ヒト血清及び上清の補体単位

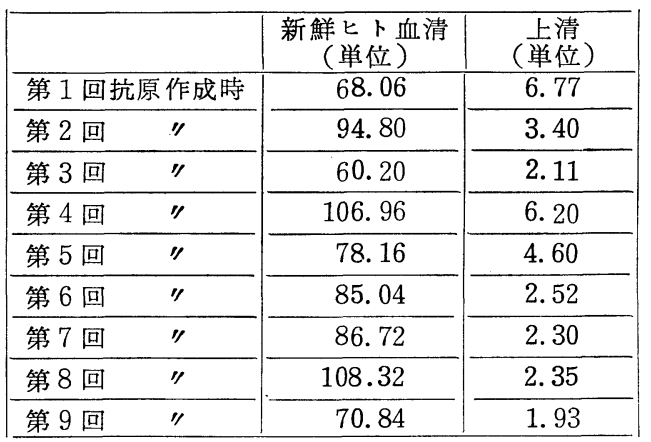

中のヒト血清の補体価は新鮮ヒト血清の $1 / 10 \sim 1 / 45$ に低下している。このことから，前述の实験方 法1 a）の免疫原作製法により $\mathrm{HC}^{\prime}$ の大部分が $\mathrm{Ew} \cdot \mathrm{ab}$ 複合物にとりこまれたことになり，沈降 物中のヒト補体の結合量は 600〜1000単位と考え られる。この沈降物中でウサギに対して持原性を もつものは卵白とヒト補体たけで，七ト補体成分 に対する抗体が産生される可能性は充分にある訳 である。また上清においては補体活性がきわめて 低下しており，従つて，実験方法 1，6）におい ては, 不活性化した上清に混じつているとト血清
の nha でRRCを感作したのであるから， $\mathrm{HC}^{\prime}$ がこれに結合することはそれほどないと考えてよ いであろう。しかも R RCに対する nha は，ヒ ト血清中の $\gamma$-globulin 分画に属すると考えられ るので, ヒト $\gamma$-globulin で感作されたRRCを もちいて免疫したことになり，ヒト血清成分に対 する抗体としては $\gamma$-globulin に対する抗体のみ が産生される可能性が考えられる。

\section{2. 抗血清の免疫電気泳動法の成樍（表 2 ）：} 抗 $\mathrm{Ew} \mathrm{ab} \mathrm{HC}$ 血清においては, ヒト血清の $\alpha_{1}$, $\alpha_{2}, \beta_{1}, \beta_{2}$-globulin 分画に分布する $3 \sim 4$ 本 の沈降带が証明されたが，albumin および $\gamma$ -

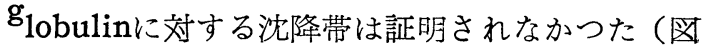

\section{表 2 とト補体結合沈降物による免疫血清と補体を とりのぞいたヒト血清で感作したウサギ赤血 球による免疫血清の特性}

\begin{tabular}{|c|c|c|c|c|c|c|c|c|c|c|}
\hline \multirow{2}{*}{ 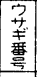 } & \multirow{2}{*}{ 免疫 原 } & Grabar & \multicolumn{4}{|c|}{ Ouchterlony } & \multicolumn{3}{|c|}{\begin{tabular}{|c|} 
面接 \\
Coambs 試験 \\
\end{tabular}} & \multirow{2}{*}{$\begin{array}{l}\text { 重層法 } \\
\text { (通原 } \\
\text { 上十四清) }\end{array}$} \\
\hline & & $\begin{array}{c}\gamma \\
1\end{array} 1^{\beta_{2}} \mid 1^{A^{\prime}}$ & 笓清 & $F-V$ & $P \mathbb{I I}$. & PII & 杭D & \begin{tabular}{|l|l|} 
\\
\end{tabular} & 杭 $L_{e}^{a}$ & \\
\hline 656 & & 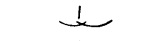 & 2 & & & & 0 & $1: 128$ & $1: 4$ & \\
\hline 658 & 卵白·抗眀白. & & 2 & 0 & I & I & 12 & 1:2256 & $1: 32$ & $4 \square^{3}$ \\
\hline 659 & 上下神体 & 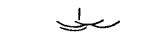 & 3 & 1 & 2 & 1 & $1: 4$ & $1: 256$ & $1: 32$ & ${ }_{s}[]^{7}$ \\
\hline 801 & 烧合沉降物 & 1 & 2 & 0 & ' & 1 & $1: 8$ & $1: 5 / 2$ & & ${ }_{4} \square^{7}$ \\
\hline 802 & $\left(E_{w} \cdot a b \cdot H C^{\prime}\right)$ & $\pi$ & 2 & 0 & I & 1 & $1: 8$ & 14096 & & ${ }_{4} \square^{8}$ \\
\hline 803 & & $\stackrel{1}{\longleftarrow}$ & 3 & 0 & 2 & 2 & $1: 64$ & 1:4096 & & $\square^{8}$ \\
\hline 799 & 棟体を除いた & 1 & ' & 0 & ' & 1 & $1: 128$ & 1.2 & & $2 \sqrt{3}^{10}$ \\
\hline 804 & 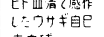 & $\longrightarrow 1$ & 1 & 0 & ' & ' & $1: 256$ & 1.4 & & ${ }_{3} \square^{9}$ \\
\hline 805 & 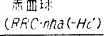 & 1 & 1 & 0 & 1 & I & 1:128 & $1: 8$ & & ${ }_{4} \square^{10}$ \\
\hline
\end{tabular}

1 ).

抗 $\mathrm{RRC} ・ \mathrm{nha}\left(-\mathrm{HC}^{\prime}\right)$ 血清では後述重層法の 成績吢示すとおり，抗体価が極めて低いためか， 一般に沈降帯の形成はわるく, No. 766, 804 のウサギにおいて，ヒト血清 $\gamma$-globulin 分画に 分布する細い沈降带の 形成が認められたが, No. 805ウサギでは証明できなかつた（図2）.

3. Ouchterlony 法の成績（表 2)：ヒト血 清, Cohn 分画の F-V., P.II 1,2 および $\mathrm{PIII}_{0}$ を 抗原としてもちい, 前述の 2 方法で免疫して得 られた抗血清の抗体分析をおこなつた。ただし， これらの Cohn 分画は前報4でものべたように 電気泳動法的には純粋でなく，P.II 1,2 は主として $\gamma$-globulin を含むほか, $\beta$-globulin もふくんで おり， $\mathrm{PIII}_{0}$ は多量の $\beta$-globulin をふくむ活か 
$\alpha$-, $\gamma$-globulin もふくんでいる. 従つておのお のの分画に対する沈降带は必ずしも1本とは限ら ず，また互に融合するものがあり，同一成分を含 んでいることを示している.その成績は表 2 の おりである。

すなわち, 抗 $\mathrm{Ew} ・ \mathrm{ab} ・ \mathrm{HC}^{\prime}$ 血清群では, ヒト 血清に対して $2 \sim 3$ 本, $\mathrm{PII}_{1}, 2$ および $\mathrm{P}-\mathrm{III}_{0} に$ 対しては夫々 1 〜 本の沈降帯をつくつたが, F－Vに対しては全く形成されなかつた。

又抗 $\mathrm{RRC} ・ \mathrm{nha}\left(-\mathrm{HC}^{\prime}\right)$ 血清では一般に沈 降带の発現が 前群に比し遲れ，3〜4日後によ うやく出現し始めた。 ヒト血清，P- $\mathrm{II}_{1,2}$, および $\mathrm{P}-\mathrm{III}_{0}$ に対してそれぞれ 1 本宛の沈降带がみら れ，しかもこれらには連絡がみられた。 F-Vに 対してはやはり沈降带の形成はみとめられなかつ た。

以上の成績からは各抗血清がもつ抗体の種類の およその推定は出来るが，決定することは難しか つた。しかしこの Ouchterlony 法の成績が免疫 電気泳動法で数種の抗-非- $\gamma$-globulin 抗体が検 出された抗 $\mathrm{Ew} a b \mathrm{HC}^{\prime}$ 血清では上述のように 数本の沈降带が形成され，抗- $\gamma$-globulin 抗体の み検出された抗 RRC nha (-HC') 血清ではそ れが単一であつたことから，両法の成績がよく一 致していることがわかる。

4. 間接 Coombs 試験の成績（表 2 ）：抗 $\mathrm{Ew}$ $\mathrm{ab} \mathrm{HC} \mathrm{HC}^{\prime}$ 血清では何れも非- $\gamma$-globulin 型の非定 型冷式抗体, 抗-Le 抗体で感作した赤血球に対し て強い凝集価を示した（非定型冷式抗体に対する 終価に 1 ：512 4096, 抗-Le 抗体に対する終価 は1：4〜1：32が， $\boldsymbol{\gamma}$-globulin 型の非定型抗 D抗体で感作した赤血球に対しては一般に低く, No803のみ 1 ：64であつたが，他は何れも 1 ： 8 以下であつた。

之に区し，抗 $\mathrm{RRC} ・ \mathrm{nha}\left(-\mathrm{HC}^{\prime}\right)$ 血清では抗

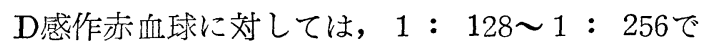
あつたが, 冷式抗体, 抗 $\mathrm{Le}^{\mathrm{a}}$ 抗体感作赤血球に 対しては $1 ： 8$ 以下の価にすぎなかつた。

したがつて，ヒト血清補体を結合したウサギ抗 体による沈降物でウサギと免疫してえられた抗血
清注，抗-非- $\gamma$-globulin 抗体を主として含み， 補体をほとんぞとりのぞいたヒト血清中の抗ウサ ギ赤血球抗体を結合したウサギ赤血球でウサギを 免疫してえられた抗血清は, 抗- $\gamma$-globulin 抗体 を主としてふくむであろうというわれわれの予想 はあたつているようである。

5. 沈降反応重層法の成績 (表 2 ). : 正常七卜 血清を抗原として両群の抗血清の沈降反応重層法 による場の形をみると，両群共大体において矩形 であつた。文免疫電気泳動法で $\alpha$-, $\beta$-globulin に対する抗体のみ検出された抗 $\mathrm{Ew} a b . \mathrm{HC}^{\prime}$ 血 清では $\mathrm{pG}_{10} 7$ 〜 , pP 4 5 であつた. 抗- $\gamma$ globulin抗体のみ検出された抗 RRC nha $\left(-\mathrm{H}^{\prime}\right)$ 血清では $\mathrm{pG}_{10} 9$ 〜 10であつたが， $\mathrm{pP} 2$ 2 4 に すぎなかつた。

\section{総括}

以上の実験成績を総括すると次のことがいえ る.

1）卵白，抗卵白血清沈降物にヒト補体を結合 させた免疫抗原をもちいて免疫した抗 $\mathrm{Ew} ・ \mathrm{ab} ・$ $\mathrm{HC}^{\prime}$ 血清では, 沈降反庎重層法の成績からもわか るように，抗体価は一般に上り易く，免疫電気 泳動法ではとト血清 $\alpha$-, $\beta$-globulin に対する抗 体のみが検出され, 間接 Coombs 試験では非- $\gamma$ globulin 型抗体 (不完全冷式抗体 (Dacie), 抗 Le $\mathrm{a}^{\mathrm{a}}$ 抗体) で感作した赤血球を強く凝集し， $\gamma$ globulin 型（抗-D抗体）抗体で感作した赤血 球汇対しては No. 803 ウサギをのでいては凝集 価はきわめて低かつた。すなわち，二の免疫方法 で, 非- $\gamma$-globulin 型非定型抗体検出に使用し得 る満足すべき Coombs 試験血清をうることがで きるといえよう。

2）前述の免疫抗原をつくるとき沈降物を除去 した上清中には，ヒト補体が殆ど結合しさられる が，この上清中のウサギ赤血球に対する異種凝集 素で感作したウサギ自己赤血球を免疫抗原として ウサギを免疫してえられた抗-RRC・nha $\left(-\mathrm{HC}^{\prime}\right)$ 血清では，抗体価はきわめて上昇しにくかつた。 したがつて免疫電気泳動法でも, Ouchterlony 法でも沈降带の形成は弱く, しかも前群に比しお 
くれて証明せられたが，前者においてはとト血清 $\gamma$-globulin に対する抗体のみが検出され，後者 においては単一な抗体が産生されていることが推 定される成績がえられた。間接 Coombs 試験で は, $\gamma$-globulin 型抗体で感作した赤血球に対す る凝集価滈く, 非- $\gamma$-globulin 型抗体で感作し た赤血球に対する凝集価は極めて低かつた。

\section{結語}

以上の実験成績から，われわれはこの実験の目 的であるヒトの非- $\gamma$-globulin ことにヒトの補体 成分に対する Coombs 血清をつくることに成功 し，免疫血液学的疾患において意味があるといわ れる $\gamma$-globulin 型抗体あるいは非- $\gamma$-globulin 型抗体（補体結合性抗体）の鑑別をたやすくする
方法を案出したものと信ずる。

\section{交献}

1) Mollison, P.L.: Blood Transfusion in Clinical Medicine, pp 299-310, Oxford, 1956.

2) Gell, G.H.: 同上301.

3）松橋直: Coombs 試験, 臨床病理, 5 (4) : 315 , 昭32.

4) 松橋直, 臼井美津子 : Coombs 試験血清の簡単 なつくり方, 医学と生物学, $42(3): 88$, 昭 32 ; Coombs 試験の特異性に関する研究, 第 1 報, Coombs試験血清のいろいろなつくり方, 同誌, $44(3): 123$, 昭 32 . 第 2 報, 免疫電気 泳動法からみたいろいろな Coombs 血清の特 長, 同誌, 46 ( 6):258, 昭33.

5) 松橋直：Coombs試験に関する諸問題，日本の 医学の 1959年一第15回日本医学会総会, 学術 集会記録一第 IV 巻 pp 142-149, 1959 . 